\title{
Archipel
}

ARCHIPEL Études interdisciplinaires sur le monde insulindien

$93 \mid 2017$

Varia

\section{Beyond the National: the Regional and Transnational Trajectories of Chinese Indonesians}

Singapore, ISEAS - Yusof Ishak Institute (20 - 21 October 2016)

\section{Mary Somers Heidhues}

\section{(Q) OpenEdition \\ Journals}

\section{Electronic version}

URL: http://journals.openedition.org/archipel/397

DOI: $10.4000 /$ archipel.397

ISSN: 2104-3655

\section{Publisher}

Association Archipel

Printed version

Date of publication: 6 June 2017

Number of pages: $9-10$

ISBN: 978-2-910513-74-0

ISSN: 0044-8613

\section{Electronic reference}

Mary Somers Heidhues, «Beyond the National: the Regional and Transnational Trajectories of Chinese Indonesians », Archipel [Online], 93 | 2017, Online since 01 June 2017, connection on 15 September 2020. URL : http://journals.openedition.org/archipel/397 


\section{Beyond the National: the Regional and Transnational Trajectories of Chinese Indonesians}

Singapore, ISEAS - Yusof Ishak Institute (20 - 21 October 2016)

In just two days, conference organizers Charlotte Setijadi, Visiting Fellow, and Hui Yew-Foong, Senior Fellow of Singapore's ISEAS - Yusof Ishak Institute gave the floor to about twenty, mostly younger researchers to discuss two aspects of the situation of Chinese Indonesians: the regional or locally rooted, and the transnational. Despite the relatively tight schedule, the meeting resulted in lively exchanges and significant insights into the situation of that minority, especially since 1998, and, perhaps, a new impetus for research.

On the "transnational" side, the first topic was that of Christian churches among Chinese, especially the rapidly growing evangelical (Chang Yau Hoon), pentecostal (Juliette Koning), and charismatic (Yumi Kiramura) varieties, with their links to preachers and co-religionists in other Asian nations. Chiou Syuan-yuan, Evi Sutrisno, and Ivana Prazic turned their attention to traditional Chinese religions, the development of Confucianism, and the celebration of Zheng He, respectively.

A more internal focus was that on pribumi (the term has been repudiated but it seems to be most convenient to describe non-Chinese Indonesians) attitudes toward Indonesia's ethnic Chinese, with analyses of interview material and internet postings by Andrew Carruthers, Thung Ju Lan, and Johanes Herlijanto - most of which showed a mixture of positive and negative opinions. Two presentations dealt with regional histories during the Revolution and the early post-revolutionary years, Yerry Wirawan about Makassar and Anne van der Veer for Medan and Pematang Siantar. The Medan-Siantar axis reappeared in Taomo Zhou's paper about the Chinese Communist Party's 
activities in Indonesia and the special role of Wang Renshu 王任叔, a literary figure known also as Baren 巴人 who later became China's first ambassador to Indonesia.

A different approach was that of Josh Steinberg, who described how Sinophone literature has had a revival in Indonesia during the last decades, some of it coming from literary associations whose members contribute and appreciate such writings. Yunita Winarto, on the other hand, gave a lively survey of the many national and international influences that make up modern Peranakan Chinese Indonesian identity in today's Java. Stefanus Suprajitno chose to question why Mandarin was considered so essential to being Chinese ("a Javanese who can't speak Javanese is still a Javanese"), and both Chontida Auikool and Chong Wu Ling returned to Medan, the first to discuss Chinese identity there, while Chong compared two contemporary political activists of Chinese origin, one from Medan, one from Surabaya.

The final session, focusing on China, directed its attention to ChineseIndonesian businessmen and Chinese investments in Indonesia (Charlotte Setijadi), reactions to importation of Chinese laborers for development projects (Nobuhiro Aizawa), and, in an interesting turn, how recent Hui migrants to Indonesia have added to the halal restaurant scene (Hew Wai Weng).

Audience participants enlivened the discussion, and a final panel, including senior scholars Charles Coppel and Leo Suryadinata, offered suggestions for new directions in research. Mary Somers Heidhues used the initial, plenary address to look back at a "long half-century" of studies of Chinese Indonesians in English and Western languages. The panel summed up the many changes in approaches, problems (citizenship, to take one example, is no longer an issue), and topics since the 1950s and 1960s, on the need for more regionally-focused studies of organization, economic activity, or language use, on challenges facing Chinese Indonesians in the age of political democratization, and above all on new questions arising from the greatly changed economic, political, and cultural relationship with China. 